\title{
Lumen
}

Selected Proceedings from the Canadian Society for Eighteenth-Century Studies

\section{German Theatre in a European Context: The Mitau Playbill}

\section{Laurence P. A. Kitching}

Volume 17, 1998

Theatre of the world

Théâtre du monde

URI : https://id.erudit.org/iderudit/1012382ar

DOI : https://doi.org/10.7202/1012382ar

Aller au sommaire du numéro

Éditeur(s)

Canadian Society for Eighteenth-Century Studies / Société canadienne d'étude du dix-huitième siècle

\section{ISSN}

1209-3696 (imprimé)

1927-8284 (numérique)

Découvrir la revue

Citer cet article

Kitching, L. P. A. (1998). German Theatre in a European Context: The Mitau Playbill. Lumen, 17, 77-90. https://doi.org/10.7202/1012382ar

Copyright (c) Canadian Society for Eighteenth-Century Studies / Sociéte canadienne d'étude du dix-huitième siècle, 1998
Ce document est protégé par la loi sur le droit d'auteur. L'utilisation des services d'Érudit (y compris la reproduction) est assujettie à sa politique d'utilisation que vous pouvez consulter en ligne.

https://apropos.erudit.org/fr/usagers/politique-dutilisation/ 


\title{
5. German Theatre in a European Context: The Mitau Playbill
}

\author{
Make sure you let enough events unfold! \\ They come to gawk, and lust for action. \\ If many a scene their eager eyes behold, \\ The crowd can gape in satisfaction. \\ By giving much and more, you will con those asses. \\ Why, you'll even be a much loved guest. \\ Mass alone will overcome the masses; \\ Each ends by picking out what he likes best. \\ Give much and you'll have given some to all, \\ And each will leave content from out this hall. \\ (Johann Wolfgang von Goethe, Faust 89-98) ${ }^{1}$
}

'Less art, more entertainment, fewer ideals, more action and adventure' could well summarize the sage advice which Goethe's knowledgeable and box-office loving theatre director in the motto above gives to his theatre poet and comic character. As will be seen in the following, such practical concerns have had to inform stage productions by leaders of strolling players, owners of established civic theatres, and directors of theatre ensembles whether courtly or middle-class since the seventeenth century.

This study surveys the period from troupes of strolling players at the end of the seventeenth century to the establishment of a Civic Theatre in late eighteenth-century Reval in Estland (corresponding to the northern one-third of present-day Estonia). Discussion focuses on an intriguing playbill which advertised a play called 'The Carnival of Venice or The Deceived Jew' (Das grosse Carneval von Venedig / oder Der betrogene Jude) for a courtly audience. ${ }^{2}$ Also, an accounts page from the ledger of Reval's first German Theatre is reproduced here for the first time, showing the enormous sums expended on genteel entertainment.

The history of German theatre in the Baltic is, of course, only of minor significance in comparison to theatre history in the German-speaking lands to the west. But as the dominant culture of the feudal Baltic ruling class was German, a German theatre came into being and served as a 
link to European culture as found in the major theatres of cities in Western Europe. Apart from recent studies by Sven Hirn, Gunilla Dahlberg, Evald Kampus and Heinrich Bosse [Jr.], little or no attention has been paid in scholarly literature to the larger picture of German theatre in the Baltic. Perhaps this was simply due to the fact that Estland was situated in Russia and the Russian Baltic provinces, beyond the often exclusively national focus of German-language scholars to the west. ${ }^{3}$ Yet in large measure, the subject matter of the German-language theatres throughout the Baltic consisted of works by well-known European, especially German and Austrian, authors and composers. In essence, the theatre-going Balts were culturally Europeans who enjoyed European taste and texts and music at home in their Russian or Swedish Baltic Sea provinces and German enclaves.

Puppeteers and troupes of German players, Teutsche Comoedianten, travelled all over Germany and Scandinavia in the 1600s, coming to Riga and Reval via Sweden in the first half of the century, as well as to Dorpat/Tartu, some $190 \mathrm{~km}$. southwest of Reval, where Gustavus II Adolphus had founded an academy in $1632 .{ }^{4}$ Over a century later, in the 1760s in his native Frankfurt, Johann Wolfgang von Goethe, ever fascinated by puppets and the theatre, saw performances by similar itinerant troupes and became familiar with their traditional repertory, including a puppet play about Faust and his damnation. Traditional concerns of leaders of wandering players and managers of permanent theatrical companies are reflected in the admonitions of the theatre director in the Vorspiel, the scene called 'Prelude in front of the Theatre,' in Goethe's Faust. These admonitions recall Samuel Johnson's more succinct words in his Prologue at the opening of the Theatre in Drury Lane: 'The drama's laws, the drama's patrons give, / For we that live to please, must please to live.'

Individual artists and European performers from Austria, Holland and German lands followed a well-travelled performance-circuit along the northern and eastern Baltic coast. Their numbers included actors as well as puppeteers, jugglers, acrobats and high wire artists. They played in German towns such as Frankfurt, Lüneburg, Berlin, Danzig and Königsberg. Near Hamburg, they travelled via the ducal castle of Gottorf in Schleswig to the Royal castle in Stockholm, and thence generally to occasional stages of the nobility or middle class in Turku, Helsinki, and Viborg. They frequented a German court theatre in St. Petersburg, artisans' guild hall stages in Reval, a nobleman's theatre in Riga and a ducal theatre in nearby Mitau (now Jelgava, Latvia, formerly Courland) until eventually some of these homeless outsiders became sedentary and accepted members of society. Respectability and a measure of prosperity and stability came with the advent of serious attempts by the nobility to 
found permanent German-language theatres; this was the case with Baron Vietinghoff in Riga and Baron von Rosen in Reval. Firm contracts enabled directors, actors and musicians to settle down and establish a repertory.

Evaluating the 37 petitions submitted by travelling players to the Reval City Council between 1630 and 1811, I must conclude that the majority of individuals and itinerant troupes had little to offer that was truly artistic. Except for the letter of Hanß Jacob Wigandt of 1630, most of the petitions fail to mention the subject matter or title of theatrical pieces by name or genre; what they had to offer was simple fare for simple people. There is no evidence in Reval archives that theatre was played in Estland from the time of the Great Northern War of 1700-1721 to the 1760s, so great had been the loss of life and property from war, famine, and plague, even among the German minority which controlled the Baltic lands and the cities. The economic, political and military events of the West and Sweden and Russia had had severe and continuous repercussions in Estland and Livland. The combined effects of the Great Northern War and accompanying plague, and the Russo-Swedish War, followed by the Seven Years' War, decimated the farms and towns, destroying the wealth of noble estate owners and patricians. ${ }^{5}$ As well, as Stefan Hartmann points out, the economic depression, particularly in Reval, caused by trade restrictions and the rise of St. Petersburg hardly allowed the town to regain its former splendour. ${ }^{6}$ Nevertheless, the Germans in the Baltic wanted their theatre and paid for it! The fact that Reval and Riga citizens in the late eighteenth century were able to afford such luxuries as the theatre deserves notice.

I have documented the history of some thirteen groups of wandering players who visited Reval in the seventeenth century. ${ }^{7}$ Analyses of the petitions by Hanß Jacob Wigandt and those of the troupes of the High German Comedians who frequented Reval, Riga and Dorpat place the tradition of the seventeenth- and eighteenth-century itinerant players into a European context, for they played in much of Europe. ${ }^{8}$ The various companies of High German Comedians who played in Dorpat and Reval in the seventeenth century seemed a sorry lot, for the most part, especially those who played in civic middle-class theatres in Reval and Dorpat.

Over 213 years ago, a more or less permanent stage came into being in 1785 in Reval, the capital of the then Russian Baltic province of Estland. The occasion coincided with the arrival of one of Europe's most entertaining playwrights to be, August Friedrich Ferdinand von Kotzebue. He had been transferred from St. Petersburg to take up a position as an official (Ober-Appellations-Assessor) at the Supreme Court in Reval. Like the famous tragic German-Baltic dramatist shortly before him, Jacob M. 
R. Lenz from Livland, Kotzebue had been secretary to Generalingenieur von Bauer, Director of the German court theatre in St. Petersburg in 1781, and had supervised the German court theatre there for a brief period after Bauer's death. But thanks to the charms of the vivacious Madame Chevalier of the French court theatre in St. Petersburg, a favourite of the Tsar, the German theatre had little chance to gain favour at the court.

Not long after his arrival in Reval, Kotzebue found an entrance into the polite society of the German nobility and the wealthy merchant class when he founded an amateur stage with them and colleagues from the Reval courts of justice. As noted by the historian, Otto-Heinrich Elias, after Kotzebue's first production, the conservative members of Reval's gracious houses felt shocked because this newcomer Kotzebue was able to attract even single and married ladies from noble and patrician families to perform in his amateur theatre. ${ }^{9}$ Establishing his experimental theatre as a charitable, not a moral, institution, Kotzebue, unlike Germany's Friedrich Schiller, promised to aid the poor and good causes by donating the proceeds of the box office via the city's welfare officials. ${ }^{10}$

Prior to the founding of a permanent German theatre in 1772 in Riga and attempts to found a similar permanent stage in Reval in 1791, the Baltic had been accustomed only to occasional theatrical productions by single entertainers, puppeteers and troupes of 6 to 15 actors; usually, a city hall or guild hall was the site of the theatre.

The noble and middle-class members of the amateur theatre society of Reval tried in 1791 to justify building a theatre by making the primary purpose of the proposed permanent building a charitable one; it was to raise money to aid the poor of Reval. Indeed, the charitable benefits of theatre performances were always a reason to allow travelling players to practise their art. On February 10, 1791, the Reval amateur theatre guild, headed by Dr. Friedrich Baron von Rosen, wrote to the Reval City Council as follows:

Conscious of the charitable purpose of this institute, applauded by the public and the vision of good works, which a comfortable theatre hall would facilitate - this commission has not given up its desire to have a comfortable theatre hall ... because it knows what kind of public it has before it and what it may expect from their love of mankind, pity and active support of all good works. We are therefore of a mind ... to erect a special building as a theatre which ... is to become the property of the public itself and whose rooms are to be used for charitable purposes ...

The building will become the property of the public. The public is the nobility of this present government and the Capital of the Government in Reval. ${ }^{11}$ 
The long-hoped-for Reval theatre was to be completed in late 1808 and stood until fire destroyed it in 1855. Thanks to its builder, Gottfried Hennig, who was also the architect and builder of the theatre in Mitau, the Reval upper classes were to initiate the opening of their first permanent theatre in 1809 - well before many a civic theatre was established in German cities to the west. As an accounts page preserved in the Reval City Archives and reproduced here in the Appendix indicates, the pleasures of the dramatic arts did not come cheaply: the total expenses for the year 1809 were Roubles 189, 687.56, of which R.40, 224.96 remained a debt. To operate the theatre that year cost some R.73, 769.32, while the box office receipts totalled an astounding R.59, 931.40. ${ }^{12}$ To what extent charitable donations could be made by the theatre guild after 1809 deserves investigating, particularly since the successes and sizable charitable donations of the preceding amateur theatre group led by August von Kotzebue in the 1780s were praised so much in the pages of Reval's weekly newspaper, the Reval(i)sche Wöchentliche Nachrichten, as indicated in a recent study. ${ }^{13}$

In Goethe's Vorspiel to Faust, the pragmatic theatre director harangues the other-worldly poet and instructs him realistically about what to write and how to lure a large, paying audience to the theatre. The thrust of what he says - less art, more entertainment - most certainly applied to the repertory of German itinerant players in all ages, especially the eighteenth century. Gotthold Ephraim Lessing had attacked the contemporary theatre, actors and repertory of the 1760s; he perceived the Hamburg theatre as devoid of original, German subject matter, and decadent, tasteless and unimaginative. He criticized the French severely for slavishly following the classical unities, holding up instead the works of Shakespeare as a model for would-be German dramatists. Both Lessing and Goethe seemed to despair of their countrymen's lack of sophistication in the theatre and tried all their lives to refine that taste in several capacities. While Lessing was a hard-hitting, demanding theatre critic at the ill-fated, fledgling Nationaltheater in Hamburg in the late 1760s, and later wrote model dramas (Minna von Barnhelm, Emilia Galotti and Nathan the Wise) for the stage, Goethe was a director of the ducal theatre in Weimar for a quarter of a century. Both created timeless works for the theatre which became dramatic masterpieces and helped fill great gaps in the indigenous repertory of the Germans.

Goethe's remarks in his ironic harangue from Faust about the extensive program demanded by eighteenth-century audiences - a great variety of the primarily visual, including dances, juggling, acrobatics, and a banal plot with lots of action and gripping scenes - are well illustrated by the description of the action and varied performances to be expected in the 'Mitau playbill,' a theatre poster of an itinerant troupe 
calling themselves 'The High German Comedians,' Die Hochteutschen Comoedianten. Likely printed in 1711, this early eighteenth-century playbill is of special interest because it suggests that the intended audience was a courtly one, possibly meeting at the ducal palace in Mitau. This advertisement was a traditional product of the playbill tradition. The emphasis on the figure of the Harlequin, as opposed to the Hanswurst or Pickelhering, reveals the emerging change in taste in dramatic and operatic literature that took place early in the eighteenth century.

\section{spit

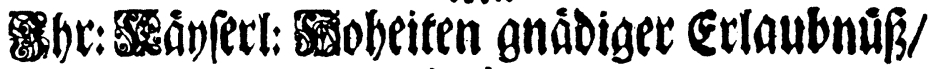 werden beute die Sodfteutfitien C O M OE D I A N T E N}

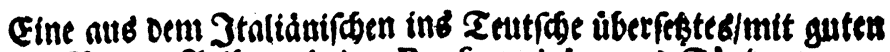
Redens:Frthen/ Arien, Præfentatiojen und Idnşen/ Harleqvins gejiemender \&uftbarlett ange: fullte betitult:

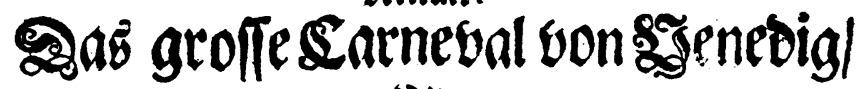

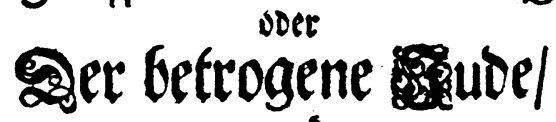

\section{uno \\ Harleqvin ein luffiger Mafqueraden- \&ruber.}

Unter andetn whro der Redouten- Saal præfentiret werden / alwo allerf̧ano

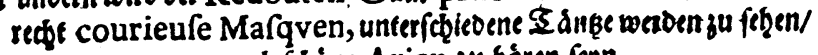
aud fojone Arien zu horen feyn.

Tacb Diefen foll gu mefreler Bemuthbs: Sergnugung sine recot

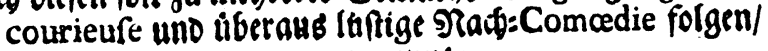
Der betrogente Geik, ooer
Die 7 verliebten Beifter.

Der Sdau Plats if aufm Stall: Die Perfohn giebr im erfen Plas 4 Eechper/ im andern

2 Eedifa. 
Because of its linguistic, lexicographical and typographic similarities to like playbills dated and printed between 1652 and 1673, it is possible that this poster was also printed during the latter half of the seventeenth century to advertise performances by Die Hochteutschen Comoedianten when they were in the area between Mitau and Reval (about a two-day journey by sailing ship from Riga) at some time between 1684 and $1690 .{ }^{14}$ Its level of sophistication suggests, however, a date in the eighteenth century. In any case, the poster is one of the oldest known surviving copies of a playbill in the German language in Western Europe.

\section{With}

The Gracious Permission of Your Imperial Highnesses/ today the High German

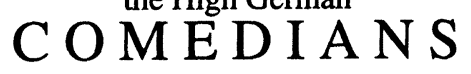

will present

A major attraction translated from the Italian/ with fine

Speeches/ Arias, Tableaux and Dances/

full of Harleqvin's appropriate Merriment/ and entitled:

\section{The great Carnival of Venice/ \\ or \\ The Deceived Jew/ \\ and \\ Harleqvin a merry Masquerade- Companion.}

Among other entertainments the Masked Ball is presented/ where all kinds of quite curious Masqves, various Dances are to be seen/ and beautiful Arias heard.

After these to delight everyone's spirits severally a very unusual and extremely funny Post-Comedy is to follow/

called:

Avarice deceived

or

The 7 enamoured Spirits

The Theatre is in the Stable Courtyard/ and begins at 4 o'clock.

Each Person gives 4 Sixers in the first Section/ in the second 2 Sixers. 
Mitau's ducal theatre was a traditional place of call for itinerant players, as were many small court cities throughout German-speaking lands, where wandering troupes could often profitably play for two weeks or more. Indeed, the Duchy of Courland appears to have been a favourite area for itinerant players. Both the seaports of Danzig and Königsberg had hosted wandering players since the mid-sixteenth century; to the east, Mitau was on a land route, the post road to Riga, Dorpat and Reval.

The 'Mitau playbill' is written in the enticing manner and jargon that indicates that we are dealing here with experienced players of musical theatre whose program is stuffed with many attractions - at least four - so as to draw as large an audience as possible. It is typical of an age in which the appeal and influence of Italian opera and Commedia dell'Arte were strong among court circles. A summary of the merry entertainment promised on the playbill suggests that it was indeed intended for such a sophisticated, courtly audience. ${ }^{15}$ The poster seeks to arouse the reader's curiosity when it announces the troupe will present the main attraction beginning at 4:00 p.m. in a courtyard. (This likely suggests summertime.) The main play has ostensibly been translated from the Italian with witty speeches, lovely arias, elegant tableaux and dances, supplemented by the appropriate merriment of the clown or Harlequin. Called 'The Great Carnival of Venice' or 'The Deceived Jew,' the title suggests that the play may have subject matter taken from Shakespeare's Merchant of Venice, first performed about 1594 and printed as early as 1600. The itinerant English players, Robert Brown, Sackeville and Bradstreet, John Green and others, popularized Shakespeare in the early 1600s in Germany when he was unknown in printed German translations. Johannes Bolte has investigated the question of the oldest German adaptation of Shakespeare's Merchant of Venice in the article 'Der Jude von Venetien - die älteste deutsche Bearbeitung des Merchant of Venice. ${ }^{16}$ It is possible that the manuscripts which he discusses are based on play texts of 1608 .

The main attraction will be followed by 'Harlequin, a merry Masquerade-Companion.' In addition, the 'Masked Ball' will be presented, during which all kinds of quite curious masques and various dances can be seen and beautiful arias heard. To cheer the spirits of all yet again a very strange and extremely funny Post-Comedy (Nachspiel), 'Avarice Deceived' or 'The 7 enamoured Spirits,' will conclude the performance.

The word 'Carnival' in the title and 'Deceived' in the subtitle of the main attraction indicate that the piece is likely a comic opera, possibly known already from Leipzig and Vienna; according to Bärbel Rudin, it could also have been played for the imperial theatre in the latter city. ${ }^{17}$ The piece is also to be understood as comic entertainment because it 'is 
replete with the Harlequin's appropriate merriment' ('Harleqvins geziemender Lustbarkeit angefüllt'). The piece entitled 'Ball Room' (Redouten-Saal) was a portrayal of a familiar sequence of festive dances, performed by masked artists. The early Singspiel, or rather arias from it, seemed to be very well known.

The variety of the performance may be seen from the troupe's offering a Nachspiel called 'Avarice Deceived' (Der betrogene Geitz). Deception was an integral part of seventeenth- and eighteenth-century comedy, whether it was a cuckolded husband or a deceiving usurer who was duped; concerning the theme of deception, David John's The German Nachspiel in the Eighteenth Century lists various Nachspiele with deception as their main thrust. ${ }^{18}$ John has no record of this particular play, which suggests perhaps a very early date for the performance. According to Rudin, this Nachspiel could well have been a Dutch 'Klucht,' that is, a coarse, amusing, one-act play which was a characteristic offering of Dutch strolling players. ${ }^{19}$

Since the playbill opens with the statement that the players have only 'Their Imperial Highnesses' permission' and since they do not mention other titles, concessions and privileges, as was common in the late seventeenth century, the troupe may fail to impress the reader that it was widely accepted. On the other hand, it may be argued that Imperial permission outranks any other.

Of course, we should be sceptical of what the leader of the troupe really means by the term 'Their Imperial Highnesses' permission.' Does the term refer to one or more persons? Are they male or female? Is the author of the poster referring to the Duke of Courland and his consort? This would be gross exaggeration, as was typical for the age, for he would be making an emperor of the Duke of Courland; in like manner, the playbill would surely not refer to the King of Sweden as 'Emperor.' There is a small possibility that the reference could have been to Polish kings whose suzerainty extended to Mitau in Courland (Kurland).$^{20}$ However, as has been seen in the scholarly literature, especially that of Eike Pies and Johannes Bolte, this particular troupe of Die Hochteutschen Comoedianten preferred to play in German-speaking territory along the Baltic coast; visits to Polish cities are rarely mentioned. ${ }^{21}$ After 1710 , the reference to Imperial privileges could suggest the Russian imperial house, but because of the length of the Great Northern War (1700-1721) and the destruction, famine and plague in its wake, it would appear questionable that the performances advertised on the playbill took place during this period.

The voice of Johannes Recke himself should be heard. He wrote the 'Table of Contents' himself for each of the three volumes of the 'Miscellanea Curlandica' which I discovered in the library of the University of 
Tartu. The Mitauer playbill is the last sheet before the empty page numbered 113 of volume three. In the 'Table of Contents,' Recke describes the sheet as follows: 'No. 35. A rare old playbill of a troupe which played in Mitau at the beginning of the 18th century.' In 1805, he also published an article, 'An old playbill printed in Mitau between 1711 and $1730^{\prime}$ and reproduced the original playbill's wording. There he writes: 'Der Freymüthige - a journal of last year, No. 107, reproduces an old playbill. Here is another, which concerns us more and can serve as an indication of what the state of the theatre in these parts may have been like at the beginning of the century. ${ }^{22}$ In a footnote, he indicates that the title 'Kayserl. Hoheiten' refers to 'The widowed Duchess Anna, an imperial Russian Princess.' As an archivist and scholar in Mitau, Recke probably knew the facts best; his assertions and his journal article make it clear that the troupe mentioned in the playbill could not have been a product of the late seventeenth century. ${ }^{23}$

This playbill does, however, seem to deserve the mention of being perhaps the second oldest recorded announced performance of Das grosse Carneval von Venedig. Indeed, the earliest performances of the comedy date from the first decade of the eighteenth century: Johann David Heinichen, a court musical director of the King of Poland and Elector of Saxony, wrote an opera in three acts in 1709 for an Easter fair in Leipzig; it was entitled, 'The Pleasant Deception or The Carnival of Venice' (Der angenehme Betrug, oder Der Carneval von Venedig). As its text was published already in 1709 , it provided the material for numerous subsequent adaptations with varying titles throughout the eighteenth century. ${ }^{24}$ Conceivably, the plot may have followed Shakespeare's Merchant of Venice closely, as indicated by a summary of the plot printed on the playbill of the Court Actors of the Prince of Hesse-Cassel from $1740 .^{25}$ Their play was announced as 'An extra gallant and well-elaborated plot entitled: "The Carnival of Venice or The Deceiver is Deceived and The feminine Jurist with Harlequin, A ridiculous Masquerade=Companion".'

In conclusion, the playbill of Das grosse Carneval in Venedig, published in the Baltic, is evidence that early in the eighteenth century, the German theatre in the region was truly European in taste and provenance. At a time when permanent theatres were situated mainly only at ducal or royal courts and in capital cities, wandering troupes from the Germanspeaking homelands spread the latest popular repertory far and wide. Members of Baltic aristocratic and upper middle-class audiences, too, were often well-travelled and familiar with the latest dramatic and theatrical events in Western Europe. As is evident, little-known documents and Baltic German newspapers in archives and libraries in Riga, 
Tallinn/Reval and Tartu/Dorpat have much to offer the historian interested in German theatre in the Baltic.

\section{LAURENCE P. A. KITCHING \\ Simon Fraser University}

\section{Endnotes}

1 English translations from the German are mine.

2 The actual German playbill is reproduced in Laurence Kitching, Europe's Itinerant Players and the Advent of German-language Theatre in Reval, Estonia - Unpublished Petitions of the Swedish Era, 1630 to 1692 (Frankfurt: Peter Lang, 1996) 94. Portions of the discussion here are indebted to a fuller analysis in that volume on 91-102.

3 See Gunilla Dahlberg, Komediantteatern i 1600-talets Stockholm. Stockholmsmonografier utgivna av Stockholms stad, 106 (Stockholm, 1992); Sven Hirn, Teater $i$ Viborg 1743-1870. Skrifter utgivna av Svenska Litteratursällskapet i Finland, Nr. 439 (Helsingfors: Svenska Litteratursällskapet i Finland, 1970); Heinrich Bosse, 'Die Etablierung des deutschen Theaters in den russischen Ostseeprovinzen um 1800,' Unerkannt und (un)bekannt - Deutsche Literatur in Mittel- und Osteuropa. (Tübingen: Francke, 1991) 79-101; also Bosse, 'The Establishment of the German Theater in 18th Century Riga,' Journal of Baltic Studies XX/3 (1989): 207-222; and Bosse, 'Die Einkünfte kurländischer Literaten am Ende des 18. Jahrhunderts,' Zeitschrift für Ostforschung 35/4 (1986): 516-594.

4 See Dahlberg, Komediantteatern. The author notes in a letter to me of 24 March 1994: 'I concentrate [there] on Stockholm, but I have also a lot of information about German theatre troupes all over Scandinavia until the beginning of the 19th century. Die Hochdeutschen Comoedianten were of utmost importance for the development of "popular theatre" in Sweden - and of course for the plays of Ludvig Holberg, the Danish national poet.'

Elisabet von Rosen, Rückblicke auf die Schauspielkunst Revals - Festschrift zur Eröffnung des neuen Theaters in Reval im September 1910. Hrsg. vom Revaler deutschen Theaterverein. Melle/Hann., 1910; reprint (Hannover-Döhren: Harro v. Hirschheydt, 1972) 13.

5 Hubertus Neuschäffer, 'Die Zeit der Aufklärung und ihre Bedeutung in den baltischen Provinzen,' Deutsche im Nordosten Europas, Hrsg. Hans Rothe. Studien zum Deutschtum im Osten, Heft 22 (Köln/Wien: Böhlau, 1991) 187-211.

6 Stefan Hartmann, 'Reval zwischen dem Nordischen und Siebenjährigen Krieg,' Deutsche im Nordosten Europas, Hrsg. Hans Rothe. Studien zum Deutschtum im Osten, Heft 22 (Köln/Wien: Böhlau, 1991) 139-166.

7 Laurence P. A. Kitching, 'German-language Theatre in Reval, Estonia during Swedish Rule: Unpublished Petitions of Strolling Players 1630-1692,' German Life and Letters (Oxford) New Series, 48:2 (April, 1995) 97-123.

'Die deutsche Wanderbühne in Reval zur Zeit der schwedischen Herrschaft - dreizehn unveröffentlichte Suppliken aus dem Revaler Stadtarchiv 1630-1692,' Maske und Kothurn (Vienna), 38. Jahrgang, Heft 1 (1996): 17-45. 
8 See for example, the permission granted to the actor Bretting in Reval, file BO 19 on November 22, 1768 :

'Da der Schauspieler Bretting sich gebührend bey Einem Kayserl.

General-Gouvernement gemeldet, und den ihn von dem privilegirten

Commoedianten Skolary ertheilten Freyheits Schein vorgezeiget: So wird ihm hirdurch nachgegeben, seinen Schau-Platz hirselbst eröffnen zu dürfen; Gleich denn derselbe des Endes an Einen WohlEdlen Magistrat verweisen wird. Revall-Schloß: 22ten Nov. 1768.

Unterschrift : gezeichnet E. A. Berg. Siegel.'

9 Cf. Otto-Heinrich Elias, 'Reval in der Reformpolitik Katherina's II. - Die Statthalterschaftszeit 1783-1796,' Quellen und Studien zur Baltischen Geschichte 3 (Bonn-Bad Godesberg, Verlag Wissenschaftliches Archiv, 1978) 173-178.

10 See the article by an anonymous author 'Mees 200 näidendiga - Kotzebue Sakslane, kes rajas Tallinnasse teatri. Esimesed etendused waeste heaks. Kuidas Wardi talupojad saide kartuli.' (The Man with 200 plays - Kotzebue - a German who established a theater in Tallinn. The first plays for the poor. How Wardi's peasant farmers got potatoes) Rahvaleht, Nr. 107 (10.IX.1937): 4.

11 Revaler Stadt Archiv, Mappe BO 21.

12 Revaler Stadt Archiv, Mappe BO 22.

13 Laurence P. A. Kitching, 'Zur Rezeptionsgeschichte des Revaler Deutschen Theaters in den Reval(i)schen Wöchentlichen Nachrichten, 1772-1852' (Schriftenreihe Thalia Germanica Series, Bd. 2), 10 pp. In press 1998.

14 Cf. Hans-Joachim Kurz und Bärbel Rudin, 'Pickelhering, rechte Frauenzimmer, berühmte Autoren - Zur Ankündigungspraxis der Wanderbühne im 17. Jahrhundert' in Wanderbühne als fahrendes Gewerbe, Bärbel Rudin, Herausgeberin. Kleine Schriften der Gesellschaft für Theatergeschichte, Heft 34/35 (Berlin: Gesellschaft für Theatergeschichte e.V., 1988) 29-61. Rudin reproduces five playbills dated between 1652 and 1673 which share common characteristics in style and typography; compare pages $34,36,42,46,48$.

15 In contrast, see Eike Pies and Ruth Eder on the raucous behaviour of troupes announcing an upcoming performance for a public of commoners as quoted in Kitching, Europe's Itinerant Players, Chap. I, notes 19 and 20, p. 51.

16 Johannes Bolte, Jahrbuch der deutschen Shakespeare-Gesellschaft, 22 [1887] (Kraus reprint, Vaduz, 1963): 189-201. See also Johannes Bolte Das Danziger Theater im 16. und 17. Jahrhundert. Theatergeschichtliche Forschungen, Bd. XII, ed. Berthold Litzmann (Hamburg / Leipzig, 1895, Reprint, Nendeln: Kraus, 1978) 119, n. 23.

17 Conversation with Bärbel Rudin, October 8, 1994.

18 David G. John, The German Nachspiel in the Eighteenth Century (Toronto: U of Toronto P, 1991) 401.

19 Conversation with Bärbel Rudin, October 8, 1994.

20 These Polish kings could have been Johann III. Sobieski, up to 1696, or the Polish-Saxon king August the Strong up to 1706 or after 1710.

21 Eike Pies. Das Theater in Schleswig 1618-1839 (Kiel: Verlag Ferdinand Hirt, 1970); Pies. Einem hoch erfreuten Publikum wird heute präsentieret eine kleine Chronik des Theaterzettels mit 21 Beispielen versetzt und vorgestellt (Hamburg \& Düsseldorf: Claassen, 1973); and Pies. Prinzipale. Zur Genealogie des deutschsprachigen 
Berufstheaters vom 17. bis 19. Jahrhundert (Düsseldorf: Aloys Henn, 1973). Also, Bolte, Jahrbuch ; and Bolte Das Danziger Theater.

22 See Wöchentliche Unterhaltungen 2 (1805): 78-79. See also J. Döring, 'Zur Geschichte des Theaters in Mitau in älterer Zeit,' Sitzungsberichte der kurländischen Gesellschaft für Literatur und Kunst 1864-1871 (Mitau: Steffenhagen, 1884) 459ff.

23 In the Mitau playbill, the 'Pickelhering' of the early seventeenth century, the comic personage of the English Comedians, is replaced by the figure of the Italian Harlequin; this may suggest a date as early as 1711 for the Mitau playbill. In other German theatre posters dating from the mid eighteenth century advertising 'The Carnival of Venice,' for example, those of Franciscus Schuch of 1748 and Ferdinand Ölperl of 1760, we observe less influence of the Italian Commedia dell'Arte. There 'Hanns Wurst' and not the Harlequin is featured in their comedies as the comic figure. I am grateful to Bärbel Rudin for pertinent bibliographical information supplied on October 8, 1994 and June 14, 1995. The designations Harlequin and Hans Wurst became synonymous for the comic personage in the eighteenth century. For scholarly investigations into these matters consult Helmut G. Asper, Spieltexte der Wanderbühne. Ein Verzeichnis der Dramenmanuskripte des 17. und 18. Jahrhunderts in Wiener Bibliotheken. Quellen zur Theatergeschichte, Hrsg. Otto G. Schindler, Band 1 (Wien: Verband der wissenschaftlichen Gesellschaften Österreichs, 1975) ch.1-2; also Erika Fischer-Lichte, Kurze Geschichte des deutschen Theaters (Tübingen/Basel: Francke, 1993) 73-80.

24 See the Herzögliche Bibliothek Gotha: Poes. 4; Sbd. 2171, Nr. 27; Stadtbibl. Hamburg: Leipziger Opernb. SCa VII, Vol. II.

25 Pertinent bibliographical information was graciously supplied by Bärbel Rudin. 


\section{APPENDIX}

\section{LEDGER PAGE FROM REVAL'S FIRST \\ GERMAN THEATRE SOCIETY}

File BO 22, Reval City Archives, p. 7

YEAR END BALANCE

30 December 1809

Übersicht über die Theaterentreprise

Debet Kuoga[?] Credit

\begin{tabular}{|c|c|c|c|}
\hline An eingenden Grunden & $28,236.92$ & Cr. eingegangen Actien & $71,500.00$ \\
\hline Baukosten & $73,769.32$ & ausstehende dito & $8,100.00$ \\
\hline Decoration & $6,696.95$ & Einnahmen bey der & \\
\hline & & Theatercassa & $59,931.40$ \\
\hline Zinsen & $2,211.19$ & Einnahmen bey der Klubbe & $4,842.10$ \\
\hline Klubb Ausgaben & $4,716.70$ & Vorschüsse an die Schauspieler & $2,042.75$ \\
\hline dito für Meubel & $1,560.00$ & & \\
\hline $\begin{array}{l}\text { Garderobe Einrichtung, } \\
\text { Gagen zur Etablierung }\end{array}$ & & & \\
\hline des Theaters & $10,872.5$ & Abonnement restactien & $2,076.50$ \\
\hline Ausgaben bey dem & & & \\
\hline Theater in diesem Jahr & $57,748.22$ & Saldo der Actien in Cassa & 729.51 \\
\hline & & dito Theater dito & 109.44 \\
\hline & & dito Klubb dito & 125.00 \\
\hline & & & 963.95 \\
\hline Vorschüsse an die & & & \\
\hline Schauspieler & $2,042.71$ & & \\
\hline Diverse Creditores & $1,826.68$ & Folglich ist die Schulden- & \\
\hline & & Last eine[n?] & $40,224.96$ \\
\hline R[ubel] & $189,687.56$ & wogegen & \\
\hline & & R[ubel] & $189,687.56$ \\
\hline & & vorgende effekten & \\
\hline & & 1/ Garderobe R. & $11,339.00$ \\
\hline & & 2/ Decoration & $7,344.00$ \\
\hline & & 3/ Lux“ & $1,240.00$ \\
\hline Reval den 30ten Decbr 18 & & 4/ Musikalische Instrumente & $1,100.00$ \\
\hline S. E. v. C & & 5/ Klub Meubel & $2,300.00$ \\
\hline & & 6/ Theater dito & 719.00 \\
\hline & & R[ubel] & $24,042.00$ \\
\hline
\end{tabular}

